\title{
Humanitarian Intervantion: The Principle of Responsibility to Protect (R2P)
}

\author{
Muhammad Zahrul Anam \\ Department of Political Sciences, International Islamic University of Malaysia \\ Email: maszahrul@gmail.com
}

Diterima pada 13 November 2014, Disetujui pada 27 Januari 2015

\begin{abstract}
This article describes the notion of the Responsibility to Protect (R2P) as a branch of humanitarian intervention. This approach emerges to immediately respond atrocities of innocent people due to political persecution taking place in a state. R2P allows external power in the form of the military operation to prevent casualties of citizen. The opponents of R2P argue that it contradicts with the non-intervention principle based on state-sovereignty. However, the proponents of this approach believe that human security and rights should be beyond of state. It is assumed that R2P remains relevant to completely stop either state violation over its citizen or armed conflict within civil war. The discussion of this paper therefore compress the notion of Humanitarian Intervention and the grounds of Humanitarian Intervention, which concerns mainly on the debate the Responsibility to Protect of what is nature of this approach, of who are authorized actors in charge as well as of how it should be implemented.

Keywords: Responsibility to Protect, Humanitarian Intervention, Conflict

Abstrak

Artikel ini menjelaskan konsep Responsibility to Protect (R2P) sebagai cabang dari intervensi kemanusiaan. Pendekatan ini muncul sebagai respon yang serius atas peristiwa pembantaian manusia tidak berdosa sebagai sanksi politik yang terjadi dalam negara. R2P mengizinkan kekuatan eksternal dalam bentuk operasi militer untuk mencegah lebih banyak kerugian jiwa dari kalangan masyarakat. Para pengkritik konsep R2P berpandangan bahwa konsep tersebut bertentangan dengan prinsip non-intervensi atas kedaulatan negara lain. Namun, para pendukung R2P menegaskan bahwa kepentingan "keamanan manusia" dan Hak Asasi Manusia berkedudukan lebih tinggi daripada (kedaulatan) negara. Hal ini kemudian mengasumsikan bahwa konsep R2P tetap relevan untuk mencegah kekerasan Negara terhadap warganya atau konflik bersenjata dalam perang saudara. Makalah ini mendiskusikan konsep Intervensi Kemanusiaan—sebagai titik tolak lahirnya R2P—dan dilanjutkan dengan dialektika R2P seputar asal-usul pendekatan ini, siapa yang memiliki otoritas melakukannya dan bagaimana konsep ini diimplementasikan.

Kata Kunci: Responsibility to protect, Intervensi kemanusiaan, Konflik
\end{abstract}

\section{INTRODUCTION}

Humanitarian intervention that explicitly allows external powers to deploy military assistance to protect innocent civilian from atrocities is debatable. The issue of military intervention has increasingly become serious concern among states since it benefited great powers to implement. Thus, this intervention is most probably a result of interpretation taken particularly by those great power countries without considering others.

The intervention paradigm seems to contradict with sovereign state paradigm all countries commonly agreed. The later paradigm believes that either individual state or a group of states cannot interfere other state's internal affairs because of its sovereignty.

Foreign armed forces sent by the great powers to deal with intra-state conflict leads to security threat in recipient country. For example, the US intervention in Iraq to stop killing Kurds people had eventually changed the regime to be the US-model democracy. Another problem is that the intervention is not 
universal.The US's double standard is main reason why the intervention is effectively implemented in non-allies US countries, whereas it does not work in the US-allies states. For example, the US strike to Libya is because of genocide. By contrast, the US is silent for thousands people of Gaza who are killed, injured and displaced because of Israel's rockets and missiles launching to their homes. Israel authority argues that Israeli military action to Gaza is legally justified to defense its territory from Palestinian terrorist attack.

Similarly, the US would not militarily intervene the powerful state in terms of military technology, geopolitics as well as strong international support. In doing so, the US costs very much on troops, finance and national security. A number of American soldiers who were killed in several wars such as the Vietnam War, the Iraq War and the Afghanistan War affect public criticism for the US intervention policy. This also increases xenophobia among non-Western people, who potentially becomes terrorists devastating the US from within.

The existence of Al-Qaida, the radical Islamic militant group, is evidence that xenophobia transforms into dangerous armed group threatening the US national security. The US citizen was surprised that 9/ 11 took place without any cautions from the US intelligent body or the authority. It illustrates that xenophobic group witnessing the US intervention worldwide has willingness to take revenge. Obviously, the US intervention is not necessarily to sacrifice the national interest, while it should protect or enhance the interest. In this regard, the US would not attack the North Korea due to the strategic position of the South Chinese Sea for international trading.

The US also must postpone to intervening Syria that has strong alliance with China, Russia and Iran. Both China and Russia are two countries of five permanent members in the United Nations Security Council that have the special rights to veto the UN Resolution. Hence, the US initiation to militarily interfere Syria would fail because of both countries. Sending weapon to opposition group in Syria is what the US can involve in this conflict situation as Iran, China and Russia do for the regime.

Implementing humanitarian intervention is not as simply as deployment of troops into conflict area or intra-state conflict circumstances. It should consider norm and strong reason the humanitarian intervention refers to. This intervention focuses mainly on 'human security', to which individual state or the International society is responsible to protect freedom from fear and freedom from want. Therefore, the idea of intervention is an attempt to sustain nature of human's freedom in proper manner, which it is threatened by violations of mass atrocities.

This paper is divided into three parts. The first part examines the concept of humanitarian intervention. The second one is explanation the notion of Responsibility to Protect (R2P), in which proponents of this tenet present the importance of R2P to secure mankind. By contrast, the opponents of R2P find that the implementation of R2P needs to be seriously discussed. The last part of the article is conclusion, to which it delivers the important point of discussion.

\section{ANALYSIS}

\section{HUMANITARIAN INTERVENTION}

The discussion and debate on humanitarian intervention begins necessarily with the role of international society. The nature of international society of what the English School approach of International Relations perceives is focused mainly on human being and their political values. The international society perspective believes that state behavior is indeed a reflection of what humans, who are involving in the process of foreign policy making, behave since both are inseparable. Therefore, the English School scholars criticize Kenneth Waltz's claim that, as pointed out by Robert Jackson and Georg Sorensen,

"there is a structure of international politics which operates with 'law-like regularity', which thus makes possible a 'scientific' theory of international politics from which 'predictions' can be derived".

Similar to Robert Jackson and Georg Sorensen 
explanation on International Society, Andrew Link later views that essential claim of the English School, to which International Society is subject matter to emphasize, is that sovereign states successfully shaping a society in existing anarchic system do not have to submit to the will or interest of a higher power.This approach acknowledges the anarchy on one hand, but it asserts that anarchy does not necessarily weaken states over the great power states on the other.

According to Hedley Bull, as explained by Adam Watson in his work, a society of states is a group of states that have certain common interests and values create a society, in which they are bound by a common set of rules in their relations with one another, and share in the working of common institutions. The vital point of this definition is legitimacy. Claude argues that state action should be constrained by 'the power of legitimacy'.Constructivist maintains that actors are embedded within normative context structured by rule. Norms themselves are not material barriers, whereas they limit power because of social disapproval. Hence, it suggests that state actor should consider legitimacy, rather than power constraint.

The illustration to describe international society obeying the rule is similar to game in which players must follow the rules they agree with. Otherwise, the players' interests would interrupt the game it tends to be chaotic. In international society, this society of states sets up particular rule, which it becomes guidance for every member of state. In this regard, states are not as agents, but structures that constrain and enable those individuals who hold positions of responsibility in the state such as presidents, chancellors, prime ministers, foreign ministers and ambassadors. In addition, the way to settle disputed rule in the society employs bargaining and coercive move rather than persuasion and appeals to common standards, shared values and accepted solutions.

In response to international society, constructivist defines a norm, which is a pivotal instrument in international society, as the existence of shared understanding as to permissible limits of state action, and acceptance that conduct should be justified and appraised in terms set by norm. The norms lead states to comply because they accept them as legitimate, whereas realism and Marxism reject that of understanding.

According to E. H. Carr, a theorist who combined elements of realism and Marxism in his thought, the norm, as perceived by scholars of the English School delivering international society, is the implementation of 'harmony of interest' doctrine, which is espoused by liberal states in the nineteenth century. He also argues that the doctrine serves the particular political and economic interests of Britain. The norm as believed by Carr must be universal principles, as what it should be, notmanipulated principles at all, as what it is. Accordingly, the normative structure of international society depends upon the distribution of power; changes in latter will lead to normative shifts as new players bring different ideologies to the world stage. Furthermore, if weaker states do not comply with the norms supported by dominant states, then they may find these being forcibly imposed upon them.

Alexander Wendt has usefully classified three approaches to explaining norm compliance, which are coercion, self-interest and legitimacy. The first approach implies that states' compliance is under militarily pressure from hegemonic state or a group of states to weaker counterparts. Wendt emphasizes that coercive imposition contrasts to legitimacy as considerably understood by theorists of the international society or the English School. Then, the second model, self-interest, suggest that states comply a norm because of rational choice, which it calculates costs and benefits in determining behaviors or actions. With respect to rational choice model, states perceive norm as an instrument to facilitate their particular interests. The last approach is legitimacy that is opposite the second model, self-interest. In this approach, states accept norms as they has already accommodated and served interests of the actors. In this the case, states recognize norms as valid.

In addition to those three approaches of what Alexander Wendt has delivered above, Jurgen 
Habermas proposes a new idea, which is called 'communicative action'. Compliance is not necessarily driven by coercive preference, model of rational choice calculation or interest-accommodated norms, but it is a result of action orientated to understanding. According to Habermas, state actors seek to persuade others to accept new moral positions based on the power of persuasion. This approach requires the openness to the arguments of others and the willingness to change a state's definition of its interest, to which Hebermas calls 'the unforced force of the better agreement'.

Hebermasians argue that a powerful claim of argument should be decided by its moral validity.

The humanitarian intervention has no uniform definition peoples such as scholars, politicians and aid agencies agree with. The term is confused by 'humanitarian action'. According to Aidan Hehir, 'humanitarian action'and 'humanitarianism' are commonly used among aid workers and non-governmental organizations (NGOs).In this context, the term of humanitarian is used to represent an altruistic, apolitical concern for human welfare. It is dangerous to integrate political agenda with humanitarian action as addressed by Cornelio Sommaruga, President of the International Committee of the Red Cross (ICRC) in the UN General Assembly in 1992:

"Humanitarian endeavor and political action must go their separate ways if the neutrality and impartiality of humanitarian work is not to be jeopardized ... it is dangerous to link humanitarian activities aimed at meeting the needs of victims of a conflict with political measures designed to bring about the settlement of the dispute between the parties"

Meanwhile, the term of humanitarian intervention is closely related to military operation. Therefore, humanitarian missions are divided into two parts. The first is traditional understanding of humanitarian focusing mainly on human need and relief. The second tenet is political consideration. The latter is the aid strategy that embraces political agenda influencing to the politics of a conflict or post-conflict situation. The humanitarian intervention also differs from the strategic military intervention. Considering the UN Charter, the use of force in international relations is not allowable. It is clearly stated in the Article 2.4:

"All members shall refrain in their international relations from the threat or use of force against the territorial integrity or political independence of any state, or in any other manner inconsistent with the Purposes of the United Nations".

On the other hand, the use of force is allowable as constituted in the Article 51 of the UN Charter in self-defense. In contras to the Article 51, Chapter VII of this Chapter strongly recommends states to ask the UN Security for approval in advance before declaring the use of force. The Article 51 is a legal basis of states to justify the force when states are attacked.

Several scholars vary in defining humanitarian intervention. Hehir compiles the number of definition as follows: the first is Roberts saying that "coercive action by one or more states involving the use of armed forces in another state without the consent of its authorities, and with the purpose of preventing widespread suffering or death among the inhabitants". Vincent defines the humanitarian intervention as

"Activity undertaken by a state, a group within state, a group of states or international organization which interferes coercively in the domestic affairs of another state. It is a discrete event having a beginning and an end, and it is aimed at the authority structure of the target state. It is not necessarily lawful or unlawful, but it does break a conventional pattern of international relations"

Welsh comments the humanitarian intervention as "Coercive interference in the internal affairs of a state, involving the use of armed force, with the purposes of addressing massive human rights violations or preventing widespread human suffering".

Another scholar is Teson arguing that humanitarian intervention is "the proportionate transboundary help, provided by governments to individuals in another state who are being denied basic human rights and who themselves would be rationally willing to 
Fig. 1

Groups rebel expecting to succeed by provoking retaliation that attract intervention

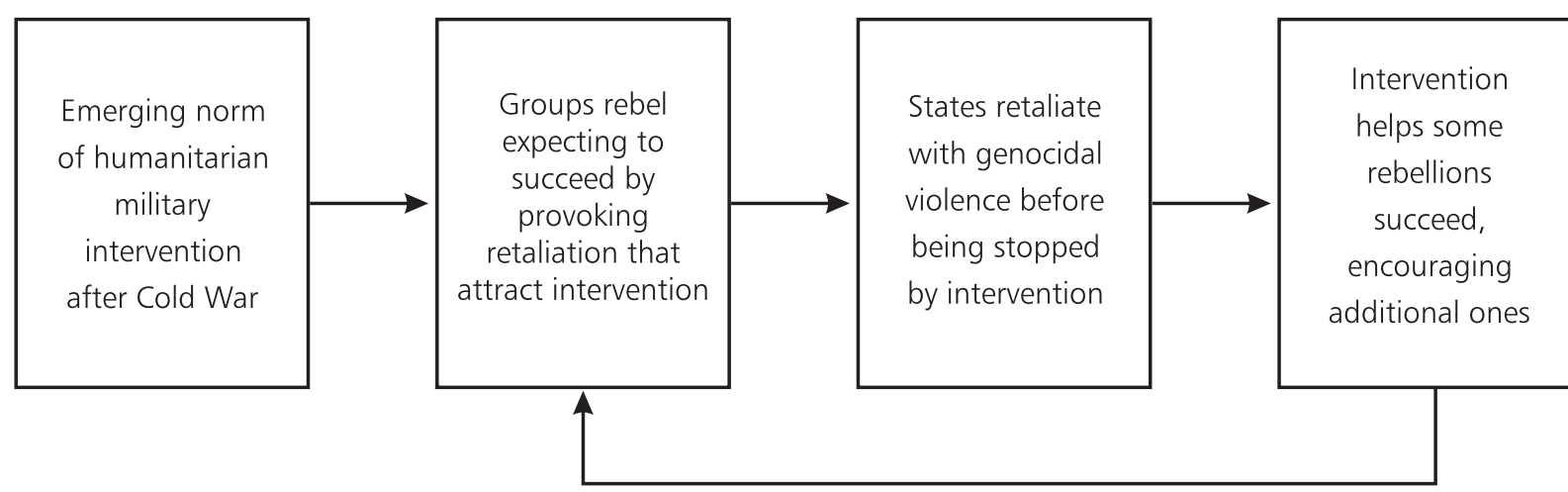

Source: Alan J. Kuperman

revolt against their oppressors".

The rise of humanitarian intervention is immediate response to numerous conflicts taking place after the end of Cold War in Haiti, Afghanistan, the Balkan and several regions of Sub-Saharan Africa. Civil wars and ethno-religious hatreds occurring in those regions had replaced East-West tensions as the principal pivot of world politics. These conflicts in turn affect atrocities and humanitarian emergencies. Considering this new development, the idea of the humanitarian intervention has emerged as a major of hope.

Alan J. Kuperman addresses an interesting theoretical point of view in dealing with the humanitarian intervention. He asserts that the common wisdom underlying this emerging norm is that humanitarian military intervention reduces the amount of genocide and ethnic cleansing (forced migration), which together can be labeled 'genocidal violence'. On the other hand, the humanitarian intervention norm may not only arise because of intra-state conflict but also it causes genocidal violence. According to Kuperman, the reason why the norm urges the violence is intentionally moral hazard, which is like insurance policy. It is assumed that the norm is a type of insurance policy against genocidal violence, whereas it also encompasses a pathology creating moral hazard that encourages risktaking. Kuperman illustrates the flowchart of possible moral hazard of humanitarian intervention as follows: (see Fig.
GROUNDS OF HUMANITARIAN INTERVENTION: THE RESPONSIBILITY TO PROTECT

This part focuses mainly on the notion of the Responsibility to Protect (R2P) as subfield of humanitarian intervention as discussed earlier. The development of this tenet is initially Kofi Annan, the Secretary General of the United Nations, initiative. In 1999, he provoked all states to abolish "another Rwanda”. What Annan wants to protect people from the worse impact of conflict escalation has attracted a number of the UN member states to completely agree establishment of the Responsibility to Protect (R2P).

R2P is finally endorsed in 2005 based on three documents. The first document is the report prepared by the International Commission on Intervention and Sovereignty (ICIS) on Threats, Challenges and Change. The second is report released by the UN Secretary General, Kofi Annan, and entitled "In Larger Freedom". The last one is WSO document, which the paragraph of 138 and 139 convinces the UN General Assembly to officially issue the Responsibility to Protect.

Sovereign state is the one that has authority and responsibility to protect its own citizen from both traditional security such as wars, armed conflicts and invasion, and non-traditional security for instance diseases, poverty as well as human trafficking. However, these security is very difficult to meet properly in a country where state is inability to protect civilians. 
In this the case, state would function as a predator threatening civilians living in. The problem is whether other states are sailent to let people suffer without any assistance, or whether they intervene to so-called state's domestic affairs. Therefore, inability of state to protect is major concern of shifting the responsibility from individual sovereign state to international society.

In terms of determining who should intervene or who has the responsibility to protect, Jam Pattison explains that people understands the term of responsibility in two things, which are broader framework and narrower one. He emphasizes that R2P is actually much broader than humanitarian intervention. It includes three parts: 1) the responsibility to prevent, 2) the responsibility to react as well as 3) responsibility to rebuild.

The responsibility to prevent is a model of international intervention in mediating two conflicting parties or giving assistance in the form of deployment of a peacekeeping force. In other words, this effort is directed to decrease tension in conflict situation that it may escalate gradually to become worse. Meanwhile, the responsibility to react is a second choice in intervening conflict reaching more dangeraous condition for innocent civilians.

This permits international society to take military action. Therefore, humanitarian intervention, according to Pattison, is one part of toolbox of the responsibility to protect. In addition, the international community should also pursue other measures, short of military intervention, such as military, diplomatic, and economic incentives and sanctions, and the use of international criminal persecutions, for example referral to to the International Criminal Court.

Morover, in the post-conflict phase, there is the responsibility to rebuild to ensure that conditions that prompted the military intervention do not repeat themselves.R2P in narrower perspective highlights that it can be implemented paticularly in a state failing to provide security within a conflict. This letter perspective seems to categorize R2P into the last resort attempt, in which international society is quite passive in applying the norm of R2P. It shows indirectly that international society should respect the existence of sovereignty.

The wide range of international society involves in conflict because it can climb in various roots of problem such as poverty, political repression and injustice distribution of resources.It is undeniable that individual state has lack of capacity to deal with those problems. Therefore, it then needs foreign assistanceand cooperation to foster participation of weak statein international market competition, to promote economic growth as well as to reform regulatory instruments and institutions.

Political repression as a result of oppresive leaders can be overcomed by political prescription. This evidence is clearly seen on the humanitarian intervension of the US in Iraq. The military operation is a mean to democratize the political system of Iraq, to which Saddam Hussain, the former President of Iraq, supressed legally the opposition movement. Regime transformation is important to maintain peace in Iraq. By promoting democracy, the external power has opportunity to do capacity building, to impose constitutional power sharing and to encourage strong civil society.

Conflict of inequal distribution is indicator of state ignorance that should be taken into account. State that fails in the law enforcement is main factor why the conflict takes place. In response to this disadvantage, the humanitarian intervention postconflict should take the law enforcement reform into consideration. The vital function of the law enforcement is to enhance protection for vulnarable groups such as ethnic minority, children and women. Looking at the complexity of causal background in intrastate conflict, the argument of broader concept of the responsibility to protect is stronger than the narrower one.

The ICIS (2001) presents six conditions allowing the intervention, which are: 1) right authority of who will legally execute to the mission, 2) just cause of objective factors to interference, 3) right intention of a merely human security purpose, 4) last resort of 
possibly working resolution, 5) proportional means and 6) reasonable prospects. Two primary causes as justification of the intervention are:

- large scale loss of life, actual or apprehended, with genocidal intent or not, which is the product either of deliberate state action, or state neglect or inability to act, or a failed state situation; or

- large scale "ethnic cleansing," actual or apprehended, whether carried out by killing, forced expulsion, acts of terror or rape.

Due to sensitivity of the intervention, all parties involving in this intervention mission should prioritize the "right intension", which is the protection of human suffering. To control this intention, the mission has to collectively be completed by the multinational forces and authorized by the UN Security Council. The ICIS states this mission as the last resort because it should be an emergency treatment, which is more effective than others. As a "short-time therapy", this mission should be proportional, which has limited scale, duration and intensity. Its primary objective is to secure civilians. What reasonable prospects mean is that the mission ensures successful achievement to halt atrocities.

The impact of conflict that can be explicitly identified is loss of lives and public facilities. In terms of public facilities as well as both formal and social finstitutions, the concept of the R2P will resolve those problems through the responsibility to rebuild. The third part of the responsibility to protect may elevate economic cooperation and internal reconciliation. Obviously, local people will receive financial aid or economic package from donors to reconstruct infrastructures, community empowerment and public services. It also provides more opportunity to reconcile between two former conflicting parties in jointly reconstructing the conflict area post-intervention.

Policy makers have faced three major problems in dealing with responsibility to rebuild: security, justice and economic development. Security issues consist of disarmament, demobilization and reintegration. The most difficult and the longest rebuilding mission is reintegration of people. Rebuilding new armed forces and police are also complicated problems. Justice becomes as paramount issues as security. The ICIS (2001) maintains that many non-governmental bodies have developed and offered "justice packages", which is the template along with peace building strategy before establishment of local institution. Post-intervention should encourage people in recreation market, sustaible development and economic growth. Several people recognize that economic restoration reflects overall recovery of the state.

The role of third party in certain armed conflict plays in number of ways. International law mentions third party involving in the conflict as an interventionist. In this regard, states of third intervionists are bound legally not to become a belligerent in the conflict rather it is involved in the rescue of nationals, Services Assisted Evacuation (SAE), protecting people within no-go zones and securing the free passage of humanitarian aid.

State or a group of states that would act as observers, monitors of the peace (or ongoing conflict if there is no peace), and supervisors of the distribution of humanitarian aid is known as interpositionary force or the peacekeepers. Joseph Starke says that the UN frequently provides observers, cease-fire monitors and military interpositionary forces for peacekeeping purposes. Starke insists that the crucial role of state is peacemaker. The major duty of peacemaker is to enforce a ceasefire by immediately stopping belligerents attacking their victims. Peacemakers must ensure that all heavy weapons are either destroyed of permanently removed from the arena of conflict. They must close down compounds that illegally restrain people.

The Responsibility to Protect is a new norm people has three different dimensions in its implementation, which are conceptional, institutional as well as political. Concerning political debate surrounding the implementation of R2P, Jonas Claes concerns this issue to discuss interestingly. Claes points out, to shift R2P from an aspiration into an accepted norm, key actors within R2P debate must also tackle the political hurdles that remain. Claes suggests the few construc- 
tive efforts to overcome R2P's political obstacles commonly include, on the one hand, efforts to consolidate the 'friends of R2P' and, on the other hand, initiatives targetting indifferent or undecided countries that so far refrained from vocal activism. The opposition group believes that political context behind R2P implementation is not given.

The way Claes analyzes countries rejecting the norm of R2P is that he detects the opposition countries in the United Nations. In 2005, Malaysia opposed the norm by arguing that R2P merely represented 'a reincarnation of humanitarian intervention, for which there was no basis in international law. Sudan delegates evaluated the norm in 2009 by reaching the opinion that giving the Security Council the previlege of being executor of the concept of the responsibility to protect would be tantamount to giving a wolf the responsibility to adopt a lam. Claes noticed that major power countries like China and Russia seemed to refrain themselves to vividly reject R2P. It has shown ambiguity since they supported the Chapter VII (SC/10187/Rev.1, 26 February 2011) resolution invoking R2P in response to atrocities committed by the Libyan government.

On the other hand, opponents of the norm of R2P decrease in number as the several controversial elements from the ICISS report disappeared already or deemphasized, and advocacy of norm entrepreneurs is very effective. Therefore, as explained by Claes, the countries like Brazil, Indonesia, India and even Vietnam agreed that the Council should take timely and decisive actionto protect populations from R2P crimes. However, the rest of countries from subSaharan Africa, the Middle East and Latin America are scptical.

The fundamental problem of why the opponents are afraid of the norm of R2P is political manipulation of the major powers that threats state's national sovereignty.The norm of R2P is possible to stimulate the Western political abuse to legitimate self-interested unilateral intervensions of 'war of conquest', referring to the wars in Iraq and Afghanistan or the NATO operation in Libya. Venezuela invited other states to refuse the norm of R2P, for it disguises the violation of sovereignty in order to promote neo-colonial interest. Claes emphazises statement coming from delegate of Nicaragua namely Miguel D'Escoto Brockmann. Brockmann said that "the legacy of colonialism gave developing countries strong reasons to fear that laudable motives can end up being misused to justify arbitrary and selective intervention against the weakest states".

In addition, Claes explains, most rejectionists also opposed the designation of a Special Adviser on the Responsibility to Protect and the funding proposal by Secretary-General Ban Ki-moon for the new Joint Office, or emphasise the potential for a 'slippery slope effect' fearing that the Responsibility to Protect could be expanded beyond the four crimes agreed upon in 2005. Others, including China and Pakistan, capitalise on the conceptual confusion surrounding R2P.

According to Claes, the general concerns of opposition coutries is about the potential erosion of national sovereignty.

Concerning opposition's general argument, Claes comes up with different idea to counter it, to which it verifies that the notion of $\mathrm{R} 2 \mathrm{P}$ is misunderstood by the opposition. The common misperceptions that the R2P debate is at its core a North-South divide, or that R2P opponents are those states most likely to experience either R2P crimes or military interventions largerly originate the urge to produce parsimonious explanations for complicated phenomena.

Claes examines whether majority of the Global South member countries are necessarily to reject the norm of the Responsibility to Protect as proposed by the Global North.The evident shows that genocide and other R2P crimes occur often in fragile states. People then initially expects that numerous countries located in the Global South are labeled as fragile or failed. Claes finds that international community faces less oppositionof the member countries in the Global Southto interfere where weak authorities are unable to protect its citizen, such as in Guenea-Bissau or Haiti.

Then, the question is whether the rejectionists are related to the Global South axis or weak states. The 
number of states, such as Kuwait, Singapore and Argentina located in the Global South, is not weak.Claes asserts that State Fragility Index in 2009 reported Sudan, Myanmar and Zimbabwe, which are of top twenty countries, explicitly oppose R2P. In fact, according to Claes, $50 \%$ of rejectionists are associated with low level of fragility. Nine of the twenty most fragile states consistently embrace R2P as an important instrument to prevent and halt mass atrocities. It is a fact that G-77 members are almost five times more likely to reject R2P, less than 16 percent of this bloc oppose the norm of R2P.

Claes says, the group of G-77 includes more than double as many supporters as opponents, some of which are friends of R2P. R2P proloferation within G77 has widened significantly. The Responsibility to Protect is also incorporated in the African Union's 2002 Constitutive Act and the institutional structure of the Economic Community (ECOWAS). Therefore, even though almost all Western countries make statements in support of R2P, the explicit support from many developing countries undermines the argument that R2P is a concept driven by the Global North. Within the Global South, rejectionists only form a fringe minority.Also, the opponent countries are not from those contries where R2P crimes are most likely to take place. Claes adds, the rejectionists are not countries where experience R2P intervention.

Therefore, another underlying factor influencing the rejectionists of $\mathrm{R} 2 \mathrm{Pshould}$ be taken into account. The point is that countries differ reason why they reject the norm of R2P. The factors, according to Claes, are seemingly to combine three political aspects, which are: 1) experience with state repression, past attrocities, and external interference, 2) tactical maneuvering as well as 3) state revisionism.

Claes comes up with three explanations regarding the first political dimension as mentioned above. The first, most rejectionists have a poor human rights record. Based on the list of the Political Terror Scale,more than half are part of select group of 'worst offenders' on the scale. Worst offenders are more than four times more likely to reject R2P than countries that do not appear on the list. These repressive countries ocassionally express their fear in private consultations that once institutionalised, R2P could adopt a historical approach and legitimise reprimands for past R2P crimes.

The second, numerous $\mathrm{R} 2 \mathrm{P}$ rejectionists justify their stance by referring to painful experiences with external interference or ill-functioning multilateral interventions. For example, Pakistan and Libya explicitly refer to illegal foreign occupations of their countries to legitimise their position. Countries may also oppose R2P due to first-hand experiences with the international community's inconsistent response to human rights abuses, or external intrusion that was not driven by humanitarian motives.

The third, it is opposite to those countries reject the norm of the Responsibility to Protect, past experience of mass atrocities and R2P crimes under previous regime can stimulate them to support the tenet of R2P such as Bosnia-Herzegovina, Chile, Argentina, Guatemala, Rwanda, Sierra Leon and Timor Leste. They are primarily rooted in humanitarian tragedies that traumatised these countries in the recent past.

In terms of tactical maneuvering, the objection of $\mathrm{R} 2 \mathrm{P}$ that occurs often in the UN meeting is a tactical way of delegates in the UN to obtain consessions. Their decisions to oppose do not correspond with the views of the head of state, let alone the population. Claes says,

"During the final discussions leading up to the 2005

World Summit, several members of G-77 and Non-Aligned Movement suddenly made significant consessions in favor of R2P after a broad commitment to the Millenium Development Goals was made. Several NAM members also assumed that an initial rejection on $\mathrm{R} 2 \mathrm{P}$ could play in a horse-trade with the broader aim of Security Council reform."

Concerning state revisionism, it reflects resistance behavior of state that wants to revise international system. States that have this particular attitude can be divided into two groups, which are: 1) the powerful 
leaders (or wolves) and 2) the weaker followers (or jackals). Randap Schweller points out, wolves symbolise relatively powerful and risk-acceptant states with strong interest in revising the current order. For example, countries like Egypt, Pakistan and Algeria use their weight within the NAM, the Asia Group, the Organization of Islamic Conference or G-77 to pursue leadership aspirations and act againt the hegemonic order of 'responsible' state behavior propagated by R2P advocates.

Meanwhile, weaker followers opposing R2P are successfully attracted by the wolves by carot and stick policy. Therefore, exclusiveeconomic and political agreements, or even military cooperation are commonplace among R2P opponents. For example, both Rusia and China colaborate closely with Venezuela, loaning billions of dollars and selling weapon to Venezuelan President Hugo Chavez who, in return, offers his natural resources to fuel the emergence of a multipolar world. It is also similar to bilateral cooperation between Syria and Iran, not to mention Bolivia, Ecuador and Venezuela.Claes suggest, countries opposing a binding global responsibility to protect human lives either willingly exclude themselves or run the risk of being isolated by the global majority.To some extent, the wolve is not threatened by the risk of isolation, such as China and Russia, because of the important role in global economy.

\section{CONCLUSION}

Despite arising considerable controversy, the norm of the Responsibility to Protect inspired by the English School approach is the best alternative humanitarian intervention to save human beings from genocide, ethnic cleansing and war crime against humanity. R2P is more than military intervention rejectionists aware of. It compresses three parts, which are Responsibility to Prevent, Responsibility to Act and Responsibility to Rebuild.

In terms of intra-state conflict, where state is disable to protect its citizen from mass atrocities, international society takes over its responsibility by preventive endeavor and continues to responsibility react by deploying troops to mitigate the worse situation of conflict. After that, international society would give assistance for post-conflict recovery. Military intervention is one part of R2P elements to minimize casualties, not to interfere state sovereignty.

Alexander Wendt comes up with three arguments to look at humanitarian intervention compliance, which are coercion, self-interest and legitimacy. The first, coercion compliance exists because hegemonic states force the weaker one. The second, the compliance is a reflection of a rational choice consideration focusing on cost and benefit. The third, this compliance is a collective awareness of the international society to recognize validity of the norm.

The opponent states of the norm argue that R2P threatens their national sovereignty.Several peoples believe that those opponents are from the Global South confronting the agenda of the Global North or countries have high-risk of R2P crimes. However, Jonas Claes maintains three reasons of rejectionists, which are 1) experience with state repression, past attrocities, and external interference, 2) tactical maneuvering 3) state revisionism.

\section{BIBLIOGRAPHY}

Claes, J. (2012). Protecting Civilians from Mass Atrocities: Meeting the Challenge of R2P Rejectionism. Global Responsibility to Protect .

Gibbs, D. N. (2009). First Do No Harm: Humanitarian Intervention and The Destruction of Yugoslavia. Nashville, Tennesee: Vanderbilt University Press.

Hehir, A. (2010). Humanitarian Intervention: An Introduction. New York, the USA: Palgrave Macmillan.

Janzekovic, J. (2000). The Use of Force in Humanitarian Intervention. Hampshire, the UK: Ashgate.

Kuperman, A. J. (2006). Suicidal Rebellions and the Moral Hazard of Humanitarian Intervention. In T. W. Kuperman (Ed.), Gambling on Humanitarian Intervention: Moral Hazard, Rebellion and Civil War. New York, the USA: Routledge.

Khong, S. (2006). Human Security and the UN: A Critical History. Bloomington, Indiana, the USA: Indiana University Press.

Man, H. (2012). Responsibility to Prevent: On the Assumed Legal Nature of Responsibility to Protect and Its Relationship with Conflict Prevention. In Responsibility to Protect: From Principle to Practice. Amsterdam, Netherland: Pallas Publications.

Pattison, J. (2010). Humanitarian Intervention and Responsibility to Protect: Who Should Intervene? New York, the USA: Oxford University Press. 
Scott Burchill, A. L.-S. (2005). Theories of International Relations. New York, the USA: Palgrave Macmillan.

Sovereignty, T. (2001). The Responsibility to Protect. Ottawa: International Department Research Center.

Sorensen, R. J. (2007). Introduction to International Relations: Theories and Approaches. New York, the USA: Oxford University Press, Inc.

Tigerstrom, B. (2007). Human Security and International Law: Prospects and Problems. Oregon, USA: Hart Publishing.

Watson, A. (1987). Hedley Bull, State System and International Societies. Review of International Studies, 13 (4).

Wheeler, N. J. (2000). Saving Stranger: Humanitarian Intervention in International Society. New York, the USA: Oxford University Press.

Wheeler, N. J. (2004). The Humanitarian Responsibilities of Sovereignty: Explaining the Development of a New Norm of Military Intervention for Humanitarian Purposes in International Society. In J. M. Welsh (Ed.), Humanitarian Intervention and International Relations. New York, the USA: Oxford University Press. 